\title{
Intrauterine death in singleton pregnancies with trisomy 21, 18, 13 and monosomy $X$
}

\author{
Vanessa Vigna Goulart ${ }^{1}$, Adolfo Wenjaw Liao ${ }^{2 *}$, Mario Henrique Burlacchini de Carvalho ${ }^{2}$, Maria de Lourdes Brizot ${ }^{2}$, \\ Rossana Pulcineli Vieira Francisco², Marcelo Zugaib ${ }^{3}$ \\ ${ }^{1} \mathrm{MSc}$ - Graduate Studant, Faculdade de Medicina, Universidade de São Paulo (FMUSP), São Paulo, SP, Brazil \\ ${ }^{2}$ Habilitation (BR: Livre Docência) - Associate Professor of Obstetrics, Department of Gynecology and Obstetrics at Faculdade de Medicina, Universidade de São Paulo (FMUSP), São Paulo, SP, Brazil \\ 3Full Professor of Obstetrics, Department of Gynecology and Obstetrics at FMUSP, São Paulo, SP, Brazil
}

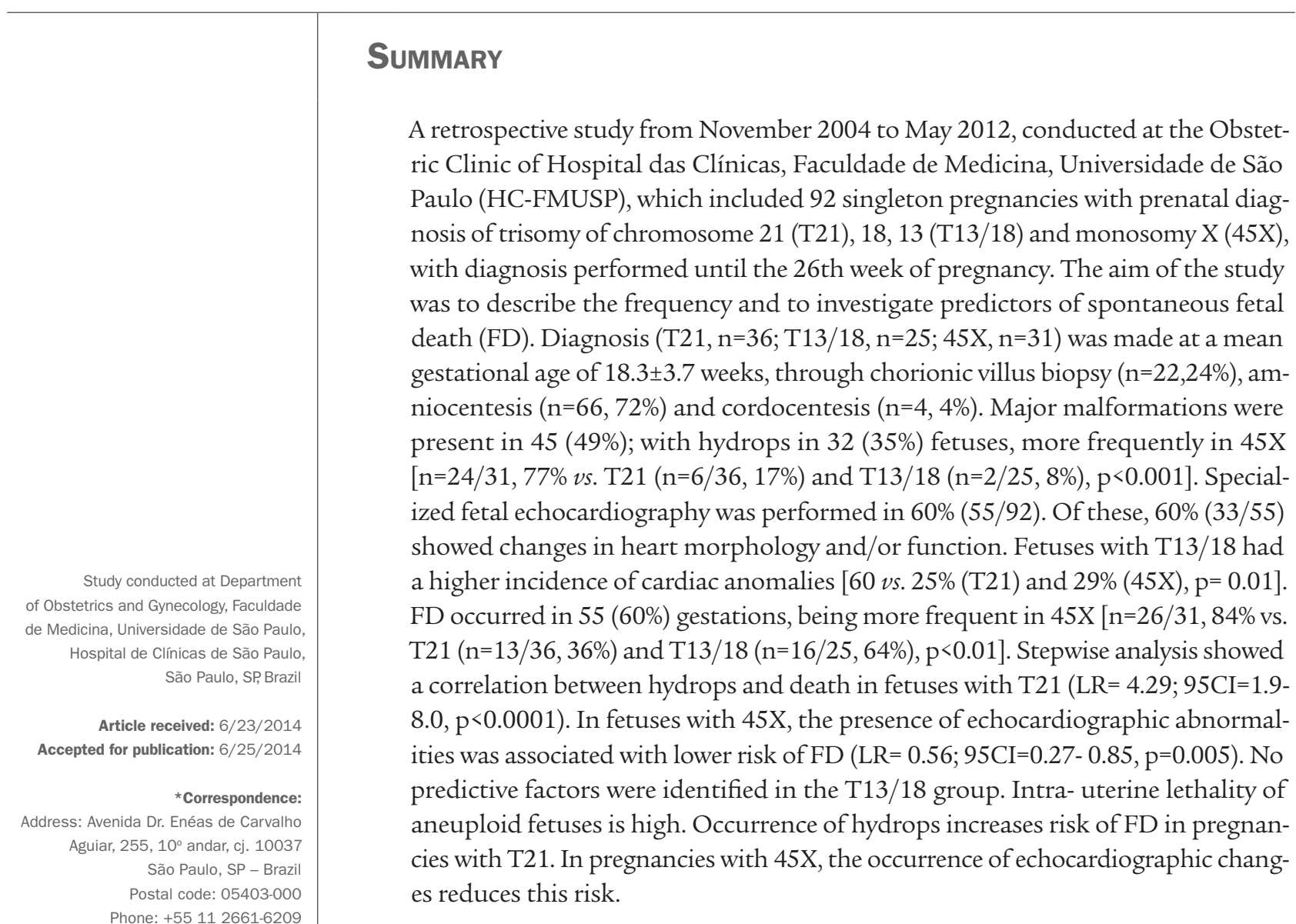

Keywords: Aneuploidy, trisomy, monosomy, fetal death, forecasting, prenatal

\section{INTRODUCTION}

Prenatal diagnosis of fetal chromosomal abnormalities is a major theme in modern perinatology. The prevalence of chromosomal abnormalities in clinically recognized abortion is about $50 \%{ }^{1}$ Aneuploid fetuses accounts for $6 \%$ of stillbirths and $11 \%$ of neonatal deaths. ${ }^{2}$ Aneuploidies that are compatible with life but bring considerable morbidity occur in $0.65 \%$ of live births. ${ }^{1,3}$ Trisomies 21 (T21), 18 and 13 (T13/18) and x-chromosome monosomy $(45 \mathrm{X})$ are the most frequent aneuploi- dies in newborns. ${ }^{4-6}$ Nowadays, tracking programs and prenatal diagnosis of such abnormalities are quite widespread. ${ }^{1}$

Conventional prenatal screening is conducted based on parameters such as maternal age (MA), and the study of ultrasound and biochemical markers. For pregnant women categorized as high risk, the assessment of fetal karyotype is offered through invasive procedures such as chorionic villus sampling (CVS) and amniocentesis (AMNIO), which carry a small but known risk of fetal loss. ${ }^{7}$ 
After demonstration of the presence of free fetal nucleic acids (DNA) in maternal plasma in 1997 by Lo et al., a range of possibilities was presented for noninvasive prenatal diagnosis of various fetal diseases, including aneuploidies. ${ }^{8}$ The great advantage of using non-invasive techniques is reducing the number of invasive procedures, and consequently loss of normal fetuses. ${ }^{89}$ Recently, several studies have validated a technology known as mass genomic sequencing, quantifying millions of DNA fragments in biological samples and providing results within days with high accuracy to detect T13/18 and T21 in early gestational age (less than 10 weeks), ${ }^{4,10-12}$ Others have demonstrated a detection rate of over $98 \%$ with a false positive rate of less than $0.5 \% .{ }^{13-20}$ Thus, non-invasive prenatal testing (NIPT) seems to be the most effective screening method in women at high risk ${ }^{21}$ and is already available at private laboratories in Brazil for tracking autosomal and sexual aneuploidies.

In many countries, the termination of pregnancies relating to aneuploid fetuses is allowed. In these cases, about $60-90 \%$ of parents choose to terminate the pregnancy after receiving the diagnosis of the abnormality. ${ }^{22-24}$ In Brazil, the current legislation does not provide permission for termination of a pregnancy in cases of chromosomal abnormalities, and this practice is typified in the country's Criminal Code. There are favorable judicial decisions for termination in the case of anomalies incompatible with life. ${ }^{25}$

It is also known that many of these fetuses die in the womb due to spontaneous mortality, which is high for aneuploidies. ${ }^{26} \mathrm{Few}$ studies describe the natural evolution of cases with abnormal karyotype, as such pregnancies are often terminated in countries where it is permitted. ${ }^{25-29}$

So, in Brazil, many parents experience the anguish of knowing that the fetus is carrying a chromosomal abnormality, which is often associated with high intrauterine or neonatal mortality rates, with the only choice being to follow the natural course.

At the Obstetrics Clinic in the Hospital das Clínicas, Faculdade de Medicina, Universidade de São Paulo (HCFMUSP), screening by measuring nuchal translucency (NT) has been offered since 1995 to all pregnant women who start prenatal care in the service or who are referred for their first trimester ultrasound. As a center of reference, the Fetal Medicine Division also receives many cases with recommendations for invasive prenatal diagnosis, referred due to the high risk of chromosomal abnormalities after ultrasound screening in the first and second trimester at other services. After diagnosis, these fetuses are monitored until the end of pregnancy.

\section{Methods}

This was a retrospective study of singleton pregnancies with prenatal diagnosis of T21, T13/18 and 45X, monitored by the Fetal Medicine Division of the HC-FMUSP Obstetrics Clinic. The research project was approved by the Ethics Committee for Research Project Analysis at the HCFMUSP on 5/31/2011. Singleton pregnancies with prenatal diagnosis of chromosome 21 (T21), 18, 13 (T13/18) trisomy and $\mathrm{X}$ monosomy $(45 \mathrm{X})$ performed until the $26^{\text {th }}$ week of gestation were included, whose parents had not sought court approved termination, and with a known outcome. Cases were identified by consulting the record books of invasive procedures for diagnosis of fetal karyotype at the Fetal Medicine Division of the HC-FMUSP Obstetrics Clinic. For each identified case, epidemiological maternal, gestational and perinatal data was collected from the electronic search of the computerized reports system in obstetrics and gynecology (SILOG) and hospital records. Patients whose final outcome occurred in other hospitals were contacted by telephone to obtain the relevant information.

The data were analyzed using the statistical software Minitab 16 (version 16.2.4, United States). The results were described according to the mean, standard deviation and absolute and relative frequencies. The comparisons between groups were conducted using the Kruskal-Wallis test and chi-square or Fisher's exact tests, if appropriate. Multivariate stepwise analysis was used to investigate the significant predictors of fetal death (FD) and included MA, parity, multiparity (two or more previous births), previous occurrence of abortions, gestational age at diagnosis, karyotype group, presence of major malformation (MF), presence of echocardiographic changes, fetal sex, and presence of fetal hydrops. The level of statistical significance was set at 0.05 . For the significant variables in the multivariate regression, likelihood ratio (LR) and confidence interval were calculated, with a confidence interval (CI) of $95 \%$.

\section{ResuLts}

181 singleton pregnancies were identified with prenatal diagnosis of chromosome $21,18,13$ trisomy or X chromosome monosomy. 97 (53.6\%) of these pregnant women underwent fetal karyotype studies at a gestational age of less than 26 weeks and had known pregnancy outcomes, with five cases terminated after court order. Thus, the final sample of this study included 92 pregnancies (T21 $n=36, T 18 n=15, T 13 n=10 ; 45 X n=31$ ).

MA ranged from 14 to 46 years, with a mean age of $32.7 \pm 8.7$, and $48 \%$ ( 44 of 92 ) aged more than 35 years. Pregnant women with fetuses carrying $45 \mathrm{X}$ had a mean 
age of $26.2 \pm 7.5$ years, significantly lower than those in the trisomy $21(37.8 \pm 5.4, \mathrm{p}<0.001)$ and trisomy $13 / 18(33.4 \pm 8.9$, $\mathrm{p}<0.001$, Table 1) groups. Gestational age at the time of the diagnostic procedure ranged from 11.9 to 26.9 weeks, with an average of $18.3 \pm 3.7$ weeks. Sixty-seven $(72.8 \%)$ fetuses were female, and 25 (27.2\%) male. Among fetuses with trisomy 21 and 13/18, 44\% (16/36) and 80\% (20/25) were female, respectively. All fetuses with the $45 \mathrm{X}$ karyotype were female.

Twenty-four percent (22 of 92) underwent chorionic villus sampling, $72 \%$ (66 of 92) amniocentesis, and 4\% (4 of 92) underwent cordocentesis. The T21, T13/18 and $45 \mathrm{X}$ subgroups did not differ regarding the distribution of the types of invasive procedures. The main indications for the fetal karyotype study were the presence of major MF in 49\% (45 of 92) of cases, the presence of ultrasound markers in 38\% (35 of 92) of cases and the presence of fetal hydrops in 35\% (32 of 92) of cases.
Forty-nine percent (45 of 92) showed MF of the fetus, $34 \%$ (31 of 92) had only one MF, $6 \%$ (6 of 92) had two MF and 9\% (8 of 92) had 3 or more MF. The frequency of at least one major MF in the T21 group was significantly lower than the T13/18 groups: T21 (12/36) vs. T13/18 $(16 / 25)$ vs. $45 \mathrm{X}(17 / 31) ; \mathrm{p}=0.045$, Table 1.

Fifty-five pregnant women underwent specialized fetal echocardiography and 33 (60\%) of these showed changes in heart morphology and/or function. The most common cardiac abnormality was ventricular septal defect (VSD), which corresponded to $39 \%$ of diagnoses. Fetuses with trisomy $13 / 18$ had a significantly higher incidence of cardiac abnormalities (60 vs. 25\% (T21) and 29\% (45X), $\mathrm{p}=0.01)$. Hydrops was identified in 32 (35\%) fetuses, and its occurrence was significantly higher in fetuses with Turner syndrome $(24 / 31,77 \%$, $\mathrm{p}<0.001)$ compared to the T21 $(6 / 36,17 \%)$ and $\mathrm{T} 13 / 18(2 / 25,8 \%)$ fetuses. FD occurred in 55 (60\%, 95CI: 49-70) fetuses, and this outcome was signif-

TABLE 1 Maternal epidemiological, gestational, clinical and perinatal characteristics in 92 pregnancies with prenatal diagnosis of trisomies 21, 18 and 13 and X monosomy at the HC-FMUSP, from May 2004 to November 2012.

\begin{tabular}{|c|c|c|c|c|c|}
\hline & All & T21 & $\mathrm{T} 13 / 18$ & $45 X$ & $\mathbf{p}^{*}$ \\
\hline n & 92 & 36 & 25 & 31 & \\
\hline \multirow[t]{2}{*}{ Maternal age in years, mean $\pm S D$} & \multirow[t]{2}{*}{$32.7 \pm 8.7$} & \multirow[t]{2}{*}{$37.8 \pm 5.4$} & \multirow[t]{2}{*}{$33.4 \pm 8.9$} & \multirow[t]{2}{*}{$26.2 \pm 7.5$} & $<0,001$ \\
\hline & & & & & $45 \mathrm{X}<\mathrm{T} 21 ; 45 \mathrm{X}<\mathrm{T} 13 / 18$ \\
\hline Primigravida, n (\%) & $43(47)$ & $12(33)$ & $12(48)$ & $19(61)$ & 0.07 \\
\hline Multigravida, n (\%) & $27(29)$ & $11(31)$ & $10(40)$ & $6(19)$ & 0.24 \\
\hline Previous abortion, n (\%) & $3(3)$ & $1(3)$ & $1(4)$ & $1(3)$ & 0.97 \\
\hline Gestational age in weeks, mean $\pm S D$ & $18.3 \pm 3.7$ & $17.9 \pm 4$ & $19.7 \pm 3.5$ & $17.6 \pm 3.2$ & 0.08 \\
\hline \multicolumn{6}{|l|}{ Procedure, n (\%) } \\
\hline Chorionic villus sampling & $22(24)$ & $11(31)$ & $6(24)$ & $5(16)$ & \multirow{3}{*}{0.28} \\
\hline Amniocentesis & $66(72)$ & $25(70)$ & $18(72)$ & $23(74)$ & \\
\hline Cordocentesis & $4(4)$ & - & $1(4)$ & $3(10)$ & \\
\hline \multicolumn{6}{|l|}{ Major malformation n (\%) } \\
\hline None & $47(51)$ & $24(67)$ & $9(36)$ & $14(45)$ & \multirow{4}{*}{$\begin{array}{l}0.045 * * \\
\text { T21<T18 }\end{array}$} \\
\hline 1 & $31(34)$ & $12(33)$ & $3(12)$ & $16(52)$ & \\
\hline 2 & $6(6)$ & - & $5(20)$ & $1(3)$ & \\
\hline$\geq 3$ & $8(9)$ & - & $8(32)$ & - & \\
\hline \multirow[t]{2}{*}{ Echocardiographic abnormality, n (\%) } & $33(36)$ & $9(25)$ & $15(60)$ & $9(29)$ & 0.01 \\
\hline & & & & & $\mathrm{T} 13 / 18>\mathrm{T} 21 ; \mathrm{T} 13 / 18>45 \mathrm{X}$ \\
\hline \multirow[t]{2}{*}{ Hydrops, n (\%) } & $32(35)$ & $6(17)$ & $2(8)$ & $24(77)$ & $<0,001$ \\
\hline & & & & & $45 \mathrm{X}>\mathrm{T} 21 ; 45 \mathrm{X}>\mathrm{t} 13 / 18$ \\
\hline \multirow[t]{2}{*}{ Male fetus, n (\%) } & $25(27)$ & $20(56)$ & $5(20)$ & - & $<0,001$ \\
\hline & & & & & $45 \mathrm{X}<\mathrm{T} 21 ; 45 \mathrm{X}<\mathrm{T} 13 / 18$ \\
\hline \multirow[t]{2}{*}{ Intrauterine death, n (\%) } & $55(60)$ & $13(36)$ & $16(64)$ & $26(84)$ & \multirow{2}{*}{$\begin{array}{l}<0,01 \\
45 \mathrm{X}>\mathrm{T} 21 ; 45 \mathrm{X}>\mathrm{T} 13 / 18\end{array}$} \\
\hline & & & & & \\
\hline
\end{tabular}

* Kruskal Wallis or chi-squared tests. SD: Standard deviation, N: Number of cases, P: Level of statistical significance.

*** Comparison between the frequencies of at least one major malformation. 
icantly more frequent in the $45 \mathrm{X}$ group $(\mathrm{n}=26 / 31,84 \%$, 95CI: $66-95 \%)$ compared to the T21 group ( $\mathrm{n}=13 / 36,36 \%$, 95CI: $21-54 \%, \mathrm{p}<0.0001)$. The rate of FD in the T13/18 group was $64 \%$ ( $\mathrm{n}=16 / 25$, 95CI: $43-82 \%$ ).

In the stepwise logistical regression analysis for prediction of FD in pregnancies with trisomy 21 , the presence of hydrops was the variable that correlated significantly with the occurrence of FD ( $\mathrm{p}<0.0001 ; \mathrm{LR}=4.29$; $95 \mathrm{CI}=1.9$ to 8.0 ), in fetuses with trisomy $13 / 18$ predictive variables of FD were not identified. For the $45 \mathrm{X}$ group, the presence of echocardiographic abnormalities was associated with a lower risk of FD ( $\mathrm{p}=0.005 ; \mathrm{LR}=0.56$; $95 \mathrm{CI}$ $=0.27-0.85$, Table 2 ).

TABLE 2 Stepwise logistic regression for prediction of fetal death in 36 pregnancies with prenatal diagnosis of trisomy 21, and 31 pregnancies with prenatal diagnosis of X monosomy - HC-FMUSP from 2004 to 2012.

Coefficient Standard $\mathrm{p}^{*}$ LR $95 \mathrm{Cl}$ error

\begin{tabular}{llllll}
\hline Trisomy 21 & \multicolumn{5}{l}{} \\
\hline Constant & 0.23 & 0.07 & 0.003 & & \\
\hline Fetal hydrops & 0.77 & 0.18 & $<0,001$ & 4.29 & $\begin{array}{l}1.87- \\
7.99\end{array}$ \\
& & & & & \\
\hline Monosomy X & & & & & \\
\hline Constant & 0.96 & 0.07 & $<0,001$ & & \\
\hline $\begin{array}{l}\text { Echocardiographic } \\
\text { abnormalities }\end{array}$ & -0.40 & 0.13 & 0.005 & 0.56 & $0.27-$ \\
*Level of significance of 0.05; LR: Likelihood ratio, Cl: Confidence interval. & & \\
\hline
\end{tabular}

\section{Discussion}

Chromosomal abnormalities are incurable congenital abnormalities. Those that are the subject of this study are the most frequent in live births, and so have the greatest impact at the social, economic and family levels. The incidence of trisomies increases with MA. ${ }^{30-36}$ Due to sociocultural changes of the last century, such as the introduction of family planning and the inclusion of women in the labor market, women have started getting pregnant later and later and so the prevalence of trisomies has increased in recent decades. ${ }^{26,37-40}$

This study was based on data obtained from tracking of aneuploid fetuses identified after fetal karyotype studies, indicated by the presence of morphological changes in ultrasound examinations in the first and/or second trimester. Only in $1 \%$ (1 of 92) of cases the karyotype study was indicated due to advanced MA. Historically, MA equal to 35 years or older was the first indication for fetal karyotype studies, but with the development of ultrasound and biochemical screening programs, advanced MA alone is used less and less to recommend karyotype studies. ${ }^{1,35,41,42}$

In 2012, Kohatsu et al. ${ }^{43}$ in a retrospective study at the HC-FMUSP Obstetrics Clinic described the indications for conducting 713 invasive procedures for studying fetal karyotype and the presence of fetal morphological changes, indicating $69.8 \%$ of the procedures. In this series, $99 \%$ of the cases had an ultrasound abnormality as an indication for karyotype studies, where the main indications were $49 \% \mathrm{MF}$ ( 45 of 92 ), $38 \%$ (35 of 92) ultrasound markers from the first and second trimester and $35 \%$ (32 of 92) fetal hydrops. This difference is justified by the fact that, in this study, all fetuses had aneuploidy, while in the study by Kohatsu et al., only $25 \%$ (187 of 713) of the fetuses were aneuploid.

Most studies that monitor the natural evolution of fetuses with prenatal diagnosis of chromosomal abnormalities use data from fetuses identified after the biochemical and/or ultrasound screening of the first and/or second trimester or sequentially. ${ }^{29,44-47}$ In Brazil, there is a public policy of screening for aneuploidy, therefore, cases with ultrasound changes in the morphological examination from the first and second trimester are referred to tertiary care centers, such as the HC-FMUSP, a situation similar to that described by Yamanaka et al. ${ }^{44}$ in a study published in Japan in 2006. In 2013, Loane et al., ${ }^{38}$ in a study using data from the European Surveillance of Congenital Anomalies (Eurocat), reported that 58\% of cases with prenatal diagnosis of T21 are identified in the ultrasound screening at the first trimester, and 16\% after combined screening (biochemical and ultrasound). Cultural, social and legal differences between countries justify the differences in the recommendations for invasive procedure for fetal karyotype studies.

In this series of cases, the average MA was $32.7 \pm 8.7$ years. The majority of observational studies between 1970 and 1990, such as that by Hook et al., ${ }^{34}$ in 1983, have a higher average MA (39.1 \pm 6.2 years), which is justified by the fact that fetal karyotype studies were, at that time, recommended for a MA greater than or equal to 35 years. In this study, the average MA for the $45 \mathrm{X}$ group was $26.2 \pm 7.5$ years, significantly lower than in the T21 and $\mathrm{T} 13 / 18$ groups $(\mathrm{p}<0.001)$. The MA for cases with $45 \mathrm{X}$ was similar to that in the study by Iyer et al., ${ }^{49}$ namely 27.9 years. The prevalence of $45 \mathrm{X}$ does not increase with MA, ${ }^{50,51}$ which justifies the lower average MA in this group.

In this study, $49 \%$ (45 of 92 ) had ultrasound findings suggesting major MF in the diagnosis procedure. In the literature, this proportion is similar, between $43 \%{ }^{52}$ and $51 \%{ }^{53}$ If considered separately by karyotype, in this sam- 
ple, the T13/18 group showed a higher frequency of MA: $64 \%$ (16 of 25). In the medical literature, the frequency of structural abnormalities in fetuses with $\mathrm{T} 13 / 18$ is high, and is found in 80 to $100 \%{ }^{26,32,47,54-56}$ In this study, of the 9 fetuses with prenatal diagnosis of T13/18 that showed no MF at the time of the karyotype studies, 6 underwent karyotype studies using CVS in the first trimester, showing an increased NT as an indication.

The association between cardiac MF and chromosomal abnormality is well known, and the medical literature indicates that cardiac abnormalities are present in about $50 \%$ of fetuses with $\mathrm{T} 21,90 \%$ of fetuses with $\mathrm{T} 18$ and $40 \%$ of those with $45 \mathrm{X}^{41}$ In this study, fifty-five pregnant women underwent specialized fetal echocardiography and 33 $(60 \%)$ showed changes in heart morphology and/or function. The most common cardiac anomaly was VSD, which corresponded to $39 \%$ of abnormal diagnoses, similar to the study by Lopes et al. ${ }^{57}$ in 2003, in which they report that out of 275 fetuses with increased NT, 24 (8.7\%) had abnormal karyotype and cardiac structural abnormalities, the most frequent being the VSD, present in 38\% ( 9 of 24 ). In this study, fetuses with trisomy $13 / 18$ had a significantly higher incidence of cardiac anomalies: 60 versus $25 \%$ (T21) and 29\% (45X). If we considered only the fetuses with T13/18 who underwent echocardiography, structural abnormalities can be found in $83 \%$ ( 15 of 18), similar to the $90 \%$ described in the literature for these anomalies. ${ }^{41,58}$

This study's intrauterine fatality rate was $60 \%$ (55 of 92) for fetuses with prenatal diagnosis of trisomies 21,18 , 13 and X monosomy from 2004 to 2012 at the HC-FMUSP. Schupp et al. ${ }^{59}$ in 2000 , in a study conducted at the HCFMUSP, reported a rate of FD of $4.48 \%$ in 11,733 births, occurring between 1993 and 1998. The fatality rate for fetuses with chromosomal abnormalities was, therefore, 14.7 times higher than in the general population within the HC-FMUSP. Saldanha et al., ${ }^{2}$ in 2009, describing the gestational outcome of 35 fetuses with chromosomal abnormalities and increased NT, also reported FD in 60\% (12 in 20 ), considering the karyotypes of T13/18, T21 and $45 \mathrm{X}$ only. In a study by Hook et al., ${ }^{34}$ in 1983, spontaneous intrauterine mortality for fetuses with the same abnormalities included in this series is $48 \%$, a possible explanation for this lower rate is that in that study the main indication for karyotype investigation was advanced MA, while in this study it was the presence of morphological changes.

For fetuses with T21, intrauterine mortality was 36\% (13 of 36) which is consistent with the findings of Hook et al. ${ }^{48}$ in 1995, in a study of 168 cases of fetuses diagnosed with T21 after AMNIO, where parents chose to continue the pregnancy, and whose intrauterine fatality rate was 35\%. In studies comparing prevalence, the mortality rate for T21 ranges between 12 and 24\% from AMNIO to birth and $30-54 \%$ from CVS to birth. ${ }^{31,60-65}$ In this study, there was no difference in the mortality rate among T21 cases diagnosed after the CVS or after AMNIO, given that 36\% (4 of 11) cases diagnosed after CVS and 36\% (9 of 25) cases diagnosed after AMNIO evolved to FD.

In the group including T13 and T18 karyotypes, the intrauterine fatality rate was $64 \%$ (16 of 25 ). In the literature, observational studies report mortality rates from 32 to $100 \%$ for T18 and from 21 to $67 \%$ for T13. ${ }^{26,29,45-47,66-70}$

For the Turner syndrome, there is a variable phenotypic expression, varying greatly in the prognosis, from a more subtle, form whose diagnosis is postnatal and causes short stature, infertility and higher frequency of aortic coarctation, up to more serious forms, with morphological abnormalities that allow prenatal diagnosis and evolve with high intrauterine mortality. ${ }^{30,71-74}$ The main ultrasound findings described in the literature are cystic hygroma and fetal hydrops, which in this sample were present in 55\% (17 of 31 ) and $77 \%$ (24 of 31 ) of fetuses with the $45 \mathrm{X}$ karyotype. In this series, intrauterine mortality was $84 \%$ ( 26 of 31 ), while in the medical literature this rate ranges from 20 to $82 \%{ }^{34,45,49,50,75,76}$

In this study, it was used multivariate stepwise logistical analysis to evaluate which findings could predict the death of aneuploid fetuses. For fetuses with T21, the presence of hydrops was the variable that correlated significantly with the occurrence of stillbirths $(\mathrm{LR}=4.29 ; 95 \mathrm{CI}=$ 1.9-8.0). The association between fetal hydrops and chromosomal abnormalities is well known, ${ }^{77-80}$ as well as the high mortality of this condition which reaches $90 \%,{ }^{79}$ although there are no specific studies in the literature demonstrating fetal hydrops as a mortality predictor for fetuses with T21.

Savva et al., ${ }^{67}$ in 2006 , evaluated 5,177 cases with prenatal diagnosis of $\mathrm{T} 21$, reporting that the risk of FD correlates with the increase in MA for fetuses diagnosed after CVS ( $p=0.04$ ), with a mortality rate of $35 \%$ for these fetuses (CI: 14-50) at age 35 and 55\% (CI: 17-30) at 45 years. This study did not find the same association for fetuses diagnosed after AMNIO. MA was not a predictor of death for fetuses with T21, as well as in the study by Hook et al., ${ }^{34}$ in 1983, where the authors compare the mean MA among live births and FD, and report no significant difference in the mean MA among cases where fetuses with prenatal diagnosis of chromosomal abnormalities survive those who die in the womb.

In 1995, Hook et al. ${ }^{45}$ published a case series with 168 cases of fetuses with prenatal diagnosis of $\mathrm{T} 21$, with ges- 
TABLE 3 Studies on intrauterine mortality of fetuses with chromosomal abnormalities.

\begin{tabular}{|c|c|c|c|c|c|c|c|}
\hline \multirow[t]{2}{*}{ Author } & \multirow[t]{2}{*}{ Year } & \multirow[t]{2}{*}{ Method* } & \multirow[t]{2}{*}{ Period** } & \multicolumn{4}{|c|}{ Intrauterine death, \% (n) } \\
\hline & & & & T13 & T18 & T21 & X0 \\
\hline Hook $^{34}$ & 1983 & direct & AMNIO & $50(4)$ & $67(21)$ & $33(52)$ & $82(11)$ \\
\hline Hook et al. ${ }^{45}$ & 1989 & direct & AMNIO & $33(3)$ & $68(15)$ & $27(37)$ & $50(4)$ \\
\hline Hook et al. ${ }^{48}$ & 1995 & direct & AMNIO & - & - & $35(168)$ & - \\
\hline \multirow{2}{*}{ Halliday et al. ${ }^{61}$} & 1995 & indirect & CVS & - & - & 31 (NR) & - \\
\hline & & & AMNIO & - & - & 18 (NR) & - \\
\hline Macintosh et al. ${ }^{62}$ & 1995 & indirect & CVS & - & - & $54(71)$ & - \\
\hline \multirow[t]{2}{*}{ Snijders et al. ${ }^{50}$} & 1995 & indirect & CVS & $83(N R)$ & $86(N R)$ & $47(N R)$ & 76 (NR) \\
\hline & & & AMNIO & 71 (NR) & 74 (NR) & 31 (NR) & 52 (NR) \\
\hline \multirow[t]{2}{*}{ Gravholt et al. ${ }^{75}$} & 1996 & direct & CVS & - & - & - & $40(5)$ \\
\hline & & & AMNIO & - & - & - & $25(8)$ \\
\hline \multirow[t]{2}{*}{ Bray e Wright ${ }^{60}$} & 1998 & indirect & CVS & - & - & 39 (NR) & - \\
\hline & & & AMNIO & - & - & 12 (NR) & - \\
\hline \multirow[t]{2}{*}{ Snijders et al. ${ }^{63}$} & 1999 & indirect & CVS & - & - & 30 (NR) & - \\
\hline & & & AMNIO & - & - & 21 (NR) & - \\
\hline \multirow[t]{2}{*}{ Morris et al. ${ }^{64}$} & 1999 & indirect & CVS & - & - & 31 (NR) & - \\
\hline & & & AMNIO & - & - & 24 (NR) & - \\
\hline \multirow[t]{2}{*}{ Cuckle $^{65}$} & 1999 & indirect & CVS & - & - & 45-46 (NR) & - \\
\hline & & & AMNIO & - & - & $22-24$ (NR) & - \\
\hline Surerus et al. ${ }^{76}$ & 2003 & direct & CVS & - & - & - & $75(8)$ \\
\hline Won et al. ${ }^{29}$ & 2005 & direct & AMNIO & - & $32(106)$ & $10(392)$ & - \\
\hline Alberman et al. ${ }^{70}$ & 2012 & direct & AMNIO & $21(N R)$ & 36 (NR) & $7(\mathrm{NR})$ & - \\
\hline Yamanaka et al. ${ }^{44}$ & 2006 & direct & AMNIO & - & $45(58)$ & - & - \\
\hline Morris e Savva ${ }^{66}$ & 2008 & direct & & $47(19)$ & $70(80)$ & - & - \\
\hline Crider et al. ${ }^{32}$ & 2008 & direct & & $50(20)$ & $63(57)$ & - & - \\
\hline Irving et al. ${ }^{26}$ & 2011 & direct & & $29(7)$ & $100(32)$ & - & - \\
\hline Lakovschek et al. ${ }^{46}$ & 2011 & direct & & $67(3)$ & $87(15)$ & - & - \\
\hline Burke et al. ${ }^{47}$ & 2013 & direct & & - & $61(23)$ & - & - \\
\hline lyer et al. ${ }^{49}$ & 2012 & direct & AMNIO/BVC & - & - & - & $40(20)$ \\
\hline
\end{tabular}

AMNIO: Amniocentesis, CVS: Chorionic villus sampling, N: Number of cases with the anomaly, NR: Not reported

* Method used: Direct monitoring of pregnancies or indirect by comparing prevalence

** Start period of monitoring (after CVS or amniocentesis up to term)

tational age at diagnosis from 12 to 38 weeks, and reported that the mortality rate is related to gestational age at diagnosis, ranging from $50 \%$ in the group diagnosed between 15 and 17 weeks, up to $20 \%$ in the group diagnosed at over 27 weeks. In this study, the gestational age at diagnosis did not correlate with FD for fetuses with T21.

For fetuses with trisomy 18/13, applying the stepwise logistical regression analysis, predictors of FD were not identifyed. Morris et al. ${ }^{66}$ published a case series in 2008, including 80 fetuses with prenatal diagnosis of T18 and, in the study, intrauterine mortality of male fetuses was higher at 79\% (95CI: 65-90\%) than deaths in females, at 67\% (95CI: 52-81\%). Other studies also suggest a higher mortality to male fetuses with $\mathrm{T} 18^{6,45,81}$ but find no cor- relation between death and fetal sex for $\mathrm{T} 13 .{ }^{6,66}$ In this study, only $20 \%$ (5 of 25) of fetuses in the T18/13 group were male and the T13 and T18 karyotypes were evaluated together. This is a possible explanation for not having identified the male sex as a predictor of death in this group.

For the 45X group, the presence of echocardiographic abnormalities was associated with a lower risk of FT $(\mathrm{LR}=0.56 ; 95 \mathrm{CI}=0.27-0.85)$. This is explained by the fact that of the 31 fetuses with the $45 \mathrm{X}$ karyotype included in this study, only 12 underwent the echocardiography requested, with 4 of the 5 that were born alive undertaking the exam, and only 8 of the 26 that died having an echocardiographic assessment. Therefore, $69 \%$ of fetuses that died in this group did not have their cardiac anatomy 
evaluated. In the medical literature, several studies have correlated the presence of fetal hydrops with poor prognosis in fetuses with $45 \mathrm{X} .77,82,83$ Using the stepwise analysis, we did not find a correlation between the presence of hydrops and increased risk of death, although it was present in $85 \%$ (22 of 26) of fetuses with 45X that died.

It is known that chromosomal abnormalities occur with increased frequency of structural defects and have high intrauterine mortality. In many countries termination of pregnancy is understood as the sole treatment for aneuploidy, especially for lethal forms. However, the legal aspects for terminating pregnancy vary widely from country to country, from permission without any specific reason to permission only to safeguard the mother's life.

In Brazil, the interruption of pregnancy can only be performed in cases of rape, to safeguard the mother's life or, more recently, when faced with the diagnosis of anencephaly. In cases of anomalies incompatible with life, as in trisomies 13 and 18 there are court decisions favoring termination, but only after a court order.

According to Gadow et al., ${ }^{24}$ in 2006, in a study conducted in Argentina - a country where termination of pregnancy after the diagnosis of chromosomal abnormality is not legally permitted - with 372 couples during counseling prior to the invasive procedure for fetal karyotyping, $68 \%$ of couples thought about terminating the pregnancy despite the practice being illegal and the mother being exposed to unsafe methods of abortion. In the same study, $87 \%$ of couples reported that the main reason for wishing to have access to a prenatal diagnosis is to receive accurate information about the health of the fetus, regardless of the possibility of termination.

In Brazil, many couples want to know the fetal karyotype to prepare for the birth. When there is a diagnosis of any chromosomal abnormality, they want to know about the prognosis of the pregnancy, the chance of the child being born alive, the presence of any fetal structural abnormalities whose treatment would be surgical, if the child will have any physical and/or mental disability and the severity of such, etc.

This study was conducted with the intention of improving the care provided to such couples. Hopefully, the findings here presented can contribute to future legal debates around the law that addresses the desire of parents for the right to decide on the fate of a pregnancy with a fetus with a chromosomal abnormality.

\section{Conclusion}

Spontaneous FD occurs in 36, 64 and $85 \%$ of pregnancies with prenatal diagnosis of trisomy $21,18,13$ and $\mathrm{X}$ monosomy, respectively. The presence of hydrops increases the risk of fetal death in pregnancies with trisomy 21. The incidence of echocardiographic abnormalities reduces this risk in pregnancies with monosomy $\mathrm{X}$.

\section{Resumo}

Óbito fetal em gestações únicas com diagnóstico de trissomias dos cromossomos 21, 18, 13 e monossomia do X

Estudo retrospectivo, de novembro de 2004 a maio de 2012, na Clínica Obstétrica do Hospital das Clínicas da Faculdade de Medicina da Universidade de São Paulo, incluindo 92 gestações únicas com diagnóstico pré-natal de trissomia dos cromossomos 21 (T21), 18, 13 (T13/18) e monossomia do X (45X), realizado até a $26^{\mathrm{a}}$ semana, com o objetivo de descrever a frequência e investigar preditores do óbito fetal espontâneo (OF). O diagnóstico (T21: n=36; T13/T18: $n=25 ; 45 X: n=31)$ foi realizado em idade gestacional média de $18,3 \pm 3,7$ semanas, por biópsia de vilo corial $(\mathrm{n}=22 ; 24 \%)$, amniocentese $(\mathrm{n}=66 ; 72 \%)$ e cordocentese $(\mathrm{n}=4 ; 4 \%)$. Malformação major presente em 45 (49\%) fetos e hidropisia em 32 (35\%), mais frequente no grupo $45 \mathrm{X}[\mathrm{n}=24 / 31,77 \%$ vs. T21 ( $\mathrm{n}=6 / 36,17 \%)$ e T13/18 ( $\mathrm{n}=2 / 25$, $8 \%) ; p<0,001]$. Ecocardiografia fetal especializada foi realizada em 60\% (55/92). Destes, 60\% (33/55) tinham alterações na morfologia e/ou na função cardíaca. Fetos com T13/18 apresentaram incidência maior de anomalias cardíacas [ 60 vs. $25 \%$ (T21) e 29\% (45X); $\mathrm{p}=0,01$ ]. Ocorrência de OF em 55 (60\%) gestações e mais frequente no grupo $45 \mathrm{X}[\mathrm{n}=26 / 31,84 \%$ vs. T21 ( $\mathrm{n}=13 / 36,36 \%)$ e T13/18 $(\mathrm{n}=16 / 25,64 \%) ; \mathrm{p}<0,01]$. Análise stepwise demonstrou associação entre hidropisia e óbito em fetos com T21 $(\mathrm{LR}=4,29 ;$ IC95\%=1,9-8,0; $\mathrm{p}<0,0001)$. Em fetos com 45X, a presença de alterações ecocardiográficas esteve associada com menor risco de OF ( $\mathrm{LR}=0,56$; $\mathrm{IC} 95 \%=0,27-0,85$; $\mathrm{p}=0,005)$. Não foram identificados fatores preditores no grupo T13/18. A letalidade intrauterina de fetos aneuploides é elevada. A presença de hidropisia aumenta o risco de $\mathrm{OF}$ em gestações com T21. Em gestações com 45X, a ocorrência de alterações ecocardiográficas reduz esse risco.

Palavras-chave: aneuploidia, trissomia, monossomia, morte fetal, previsões, diagnóstico pré-natal.

\section{References}

1. College of Obstetricians and Gynecologists. ACOG Practice Bulletin No. 88, December 2007. Invasive prenatal testing for aneuploidy. Obstet Gynecol. 2007; 110(6):1459-67. 
2. Saldanha F, Brizot M, Lopes L, Liao A, Zugaib M. Fetal abnormalities and prognosis associated with increased nuchal translucency and abnormal karyotype. Rev Assoc Med Bras. 2009; 55(1):54-9.

3. Bulletins ACoP. ACOG Practice Bulletin No. 77: screening for fetal chromosomal abnormalities. Obstet Gynecol. 2007; 109(1):217-27.

4. Liao GJ, Chiu RW, Lo YM. Prenatal assessment of fetal chromosomal and genetic disorders through maternal plasma DNA analysis. Pathology. 2012; 44(2):69-72.

5. Vendola C, Canfield M, Daiger SP, Gambello M, Hashmi SS, King T, et al. Survival of Texas infants born with trisomies 21, 18, and 13. Am J Med Genet A. 2010; 152A(2):360-6

6. Huether CA, Martin RL, Stoppelman SM, DSouza S, Bishop JK, Torfs CP, et al. Sex ratios in fetuses and liveborn infants with autosomal aneuploidy. Am J Med Genet A. 1996; 63(3):492-500.

7. Neagos D, Cretu R, Sfetea RC, Bohiltea LC. The importance of screening and prenatal diagnosis in the identification of the numerical chromosomal abnormalities. Maedica (Buchar). 2011; 6(3):179-84.

8. Lo YM, Corbetta N, Chamberlain PF, Rai V, Sargent IL, Redman CW, et al Presence of fetal DNA in maternal plasma and serum. Lancet. 1997; 350(9076):485-7.

9. Liao GJ, Lun FM, Zheng YW, Chan KC, Leung TY, Lau TK, et al. Targeted massively parallel sequencing of maternal plasma DNA permits efficient and unbiased detection of fetal alleles. Clin Chem. 2011; 57(1):92-101.

10. Liao GJ, Chan KC, Jiang P, Sun H, Leung TY, Chiu RW, et al. Noninvasive prenatal diagnosis of fetal trisomy 21 by allelic ratio analysis using targeted massively parallel sequencing of maternal plasma DNA. PLoS One. 2012; 7(5):e38154.

11. Lo YM. Non-invasive prenatal diagnosis by massively parallel sequencing of maternal plasma DNA. Open Biol. 2012; 2(6):120086.

12. Sehnert AJ, Rhees B, Comstock D, de Feo E, Heilek G, Burke J, et al. Optimal detection of fetal chromosomal abnormalities by massively parallel DNA sequencing of cell-free fetal DNA from maternal blood. Clin Chem. 2011; 57(7):1042-9.

13. Chiu RW, Akolekar R, Zheng YW, Leung TY, Sun H, Chan KC, et al. Noninvasive prenatal assessment of trisomy 21 by multiplexed maternal plasma DNA sequencing: large scale validity study. BMJ. 2011; 342:c7401.

14. Ehrich M, Deciu C, Zwiefelhofer T, Tynan JA, Cagasan L, Tim R, et al. Noninvasive detection of fetal trisomy 21 by sequencing of DNA in maternal blood: a study in a clinical setting. Am J Obstet Gynecol. 2011; 204(3):205.e1-11.

15. Palomaki GE, Kloza EM, Lambert-Messerlian GM, Haddow JE, Neveux LM, Ehrich M, et al. DNA sequencing of maternal plasma to detect Down syndrome: an international clinical validation study. Genet Med. 2011; 13(11):913-20.

16. Palomaki GE, Deciu C, Kloza EM, Lambert-Messerlian GM, Haddow JE, Neveux LM, et al. DNA sequencing of maternal plasma reliably identifies trisomy 18 and trisomy 13 as well as Down syndrome: an international collaborative study. Genet Med. 2012; 14(3):296-305.

17. Sparks AB, Wang ET, Struble CA, Barrett W, Stokowski R, McBride C, et al Selective analysis of cell-free DNA in maternal blood for evaluation of fetal trisomy. Prenat Diagn. 2012; 32(1):3-9.

18. Norton ME, Brar H, Weiss J, Karimi A, Laurent LC, Caughey AB, et al. NonInvasive chromosomal evaluation (NICE) study: results of a multicenter prospective cohort study for detection of fetal trisomy 21 and trisomy 18 . Am J Obstet Gynecol. 2012; 207(2):137.e1-8.

19. Chen EZ, Chiu RW, Sun H, Akolekar R, Chan KC, Leung TY, et al. Noninvasive prenatal diagnosis of fetal trisomy 18 and trisomy 13 by maternal plasma DNA sequencing. PLoS One. 2011; 6(7):e21791.

20. Bianchi DW, Platt LD, Goldberg JD, Abuhamad AZ, Sehnert AJ, Rava RP, et al. Genome-wide fetal aneuploidy detection by maternal plasma DNA sequencing. Obstet Gynecol. 2012; 119(5):890-901.

21. American College of Obstetricians and Gynecologists Committee on Genetics. Committee Opinion No. 545: Noninvasive prenatal testing for fetal aneuploidy. Obstet Gynecol. 2012; 120(6):1532-4

22. Verp MS, Bombard AT, Simpson JL, Elias S. Parental decision following prenatal diagnosis of fetal chromosome abnormality. Am J Med Genet. 1988; 29(3):613-22.

23. Hawkins A, Stenzel A, Taylor J, Chock V, Hudgins L. Variables influencing pregnancy termination following prenatal diagnosis of fetal chromosome abnormalities. Stanford: Stanford University Perinatal Genetics, 2013. p.238-48.

24. Gadow E, Petracchi F, Igarzabal L, Gadow A, Quadrelli R, Krupitzki H. Awareness and attitude toward prenatal diagnosis of chromosomal abnormalities in patients with no access to legal termination of pregnancy. Prenat Diagn. 2006; 26(10):885-91.
25. Ramos JL, Carvalho MH, Zugaib M. [Socio demographic characterization and perinatal outcome of pregnancies with ultrasonographic diagnosis of major fetal malformation in a referral centre]. Rev Assoc Med Bras. 2009; 55(4):447-51.

26. Irving C, Richmond S, Wren C, Longster C, Embleton ND. Changes in fetal prevalence and outcome for trisomies 13 and 18: a population-based study over 23 years. J Matern Fetal Neonatal Med. 2011; 24(1):137-41.

27. Yamanaka M, Setoyama T, Igarashi Y, Kurosawa K, Itani Y, Hashimoto S, et al. Pregnancy outcome of fetuses with trisomy 18 identified by prenatal sonography and chromosomal analysis in a perinatal center. Am J Med Genet A. 2006; 140(11):1177-82

28. Saldanha FA, Brizot MeL, Lopes LM, Liao AW, Zugaib M. [Fetal abnormalities and prognosis associated with increased nuchal translucency and abnormal karyotype]. Rev Assoc Med Bras. 2009; 55(1):54-9.

29. Won RH, Currier RJ, Lorey F, Towner DR. The timing of demise in fetuses with trisomy 21 and trisomy 18. Prenat Diagn. 2005; 25(7):608-11.

30. Snijders RJ, Holzgreve W, Cuckle H, Nicolaides KH. Maternal age-specific risks for trisomies at 9-14 weeks gestation. Prenat Diagn. 1994; 14(7):543-52

31. Snijders RJ, Sebire NJ, Nicolaides KH. Maternal age and gestational age-specific risk for chromosomal defects. Fetal Diagn Ther. 1995; 10(6):356-67.

32. Crider KS, Olney RS, Cragan JD. Trisomies 13 and 18: population prevalences, characteristics, and prenatal diagnosis, metropolitan Atlanta, 1994-2003. Am J Med Genet A. 2008; 146(7):820-6.

33. Cuckle HS, Wald NJ, Thompson SG. Estimating a woman's risk of having a pregnancy associated with Down's syndrome using her age and serum alpha-fetoprotein level. Br J Obstet Gynaecol. 1987; 94(5):387-402.

34. Hook EB. Chromosome abnormalities and spontaneous fetal death following amniocentesis: further data and associations with maternal age. Am J Hum Genet. 1983; 35(1):110-6

35. Nicolaides KH, Sebire NJ, Snijders RJ, Johnson S. Down's syndrome screening in the UK. Lancet. 1996; 347(9005):906-7.

36. Resta RG. Changing demographics of advanced maternal age (AMA) and the impact on the predicted incidence of Down syndrome in the United States: implications for prenatal screening and genetic counseling. Am J Med Genet A. 2005; 133A(1):31-6.

37. Tonks AM, Gornall AS, Larkins SA, Gardosi JO. Trisomies 18 and 13: trends in prevalence and prenatal diagnosis - population based study. Prenat Diagn 2013; 33(8):742-50.

38. Loane M, Morris JK, Addor MC, Arriola L, Budd J, Doray B, et al. Twenty-year trends in the prevalence of Down syndrome and other trisomies in Europe: impact of maternal age and prenatal screening. Eur J Hum Genet. 2013; 21(1):27-33.

39. Baird PA, Sadovnick AD. Maternal age-specific rates for Down syndrome: changes over time. Am J Med Genet.1988; 29(4):917-27.

40. Cocchi G, Gualdi S, Bower C, Halliday J, Jonsson B, Myrelid A, et al International trends of Down syndrome 1993-2004: Births in relation to maternal age and terminations of pregnancies. Birth Defects Res A Clin Mol Teratol. 2010; 88(6):474-9.

41. Nicolaides K, Shawwa L, Brizot M, Snijders R. Ultrasonographically detectable markers of fetal chromosomal defects. Ultrasound Obstet Gynecol. 1993; 3(1):56-69.

42. Brizot MeL, Zugaib M. [Should nuchal translucency be requested in prenatal care?]. Rev Assoc Med Bras. 2003; 49(4):356-7.

43. Kohatsu M, Carvalho MH, Vieira Francisco RP, Amorim Filho AG, Zugaib $M$. Analysis of fetal and maternal results from fetal genetic invasive procedures: an exploratory study at a University Hospital. Rev Assoc Med Bras. 2012; 58(6):703-8.

44. Yamanaka M, Setoyama T, Igarashi Y, Kurosawa K, Itani Y, Hashimoto S, et al. Pregnancy outcome of fetuses with trisomy 18 identified by prenatal sonography and chromosomal analysis in a perinatal center. Am J Med Genet A. 2006; 140(11):1177-82.

45. Hook EB, Topol BB, Cross PK. The natural history of cytogenetically abnormal fetuses detected at midtrimester amniocentesis which are not terminated electively: new data and estimates of the excess and relative risk of late fetal death associated with 47,21 and some other abnormal karyotypes. Am J Hum Genet. 1989; 45(6):855-61.

46. Lakovschek IC, Streubel B, Ulm B. Natural outcome of trisomy 13, trisomy 18, and triploidy after prenatal diagnosis. Am J Med Genet A. 2011; 155A(11):2626-33.

47. Burke AL, Field K, Morrison JJ. Natural history of fetal trisomy 18 after prenatal diagnosis. Arch Dis Child Fetal Neonatal Ed. 2013; 98(2):F152-4.

48. Hook EB, Mutton DE, Ide R, Alberman E, Bobrow M. The natural history of Down syndrome conceptuses diagnosed prenatally that are not electively terminated. Am J Hum Genet. 1995; 57(4):875-81. 
49. Iyer NP, Tucker DF, Roberts SH, Moselhi M, Morgan M, Matthes JW Outcome of fetuses with Turner syndrome: a 10-year congenital anomaly register based study. J Matern Fetal Neonatal Med. 2012; 25(1):68-73.

50. Snijders R, Sebire NHC, Nicolaides K. Maternal age and gestational agespecific risk for chromosomal defects. Fetal Diag Ther. 1995; 10(6):356-67.

51. Warburton D, Kline J, Stein Z, Susser M. Monosomy X: a chromosomal anomaly associated with young maternal age. Lancet. 1980; 1(8161):167-9.

52. Dicke JM, Crane JP. Sonographic recognition of major malformations and aberrant fetal growth in trisomic fetuses. J Ultrasound Med. 1991; 10(8):433-8.

53. Benacerraf BR, Neuberg D, Bromley B, Frigoletto FD. Sonographic scoring index for prenatal detection of chromosomal abnormalities. J Ultrasound Med. 1992; 11(9):449-58.

54. Brun L, Dufour P, Savary JB, Valat AS, Boute O, Subtil D, et al. [Trisomy 18 : ultrasound aspects. Report of 40 cases]. Presse Med. 2000; 29(38):2082-6.

55. Bronsteen R, Lee W, Vettraino IM, Huang R, Comstock CH. Second-trimester sonography and trisomy 18. J Ultrasound Med. 2004; 23(2):233-40.

56. Yeo L, Guzman ER, Day-Salvatore D, Walters C, Chavez D, Vintzileos AM Prenatal detection of fetal trisomy 18 through abnormal sonographic features. J Ultrasound Med. 2003; 22(6):581-90; quiz 91-2.

57. Lopes LM, Brizot ML, Lopes MA, Ayello VD, Schultz R, Zugaib M. Structural and functional cardiac abnormalities identified prior to 16 weeks gestation in fetuses with increased nuchal translucency. Ultrasound Obstet Gynecol $2003 ; 22(5): 470-8$

58. Embleton N, Wyllie J, Wright M, Burn J, Hunter S. Natural history of trisomy 18 Arch Dis Child Fetal Neonatal Ed. 1996; 75(1):F38-F41.

59. Schupp TR, Miyadahira S, Kahhale S, Zugaib M. Management of pregnancy in a university hospital: a 6-year study. Rev Hosp Clin Fac Med São Paulo. 2000; 55(4):137-44

60. Bray IC, Wright DE. Estimating the spontaneous loss of Down syndrome fetuses between the times of chorionic villus sampling, amniocentesis and live birth. Prenat Diagn. 1998; 18(10):1045-54.

61. Halliday JL, Watson LF, Lumley J, Danks DM, Sheffield LJ. New estimates of Down syndrome risks at chorionic villus sampling, amniocentesis, and live birth in women of advanced maternal age from a uniquely defined population. Prenat Diagn. 1995; 15(5):455-65.

62. Macintosh MC, Wald NJ, Chard T, Hansen J, Mikkelsen M, Therkelsen AJ, et al. Selective miscarriage of Down's syndrome fetuses in women aged 35 years and older. Br J Obstet Gynaecol. 1995; 102(10):798-801.

63. Snijders R, Sundberg K, Holzgreve W, Henry G, Nicolaides K. Maternal age and gestation-specific risk for trisomy 21. Ultrassound Obstet Gynecol. 1999; 13(3):167-70

64. Morris JK, Wald NJ, Watt HC. Fetal loss in Down syndrome pregnancies. Prenat Diagn. 1999; 19(2):142-5.
65. Cuckle H. Down syndrome fetal loss rate in early pregnancy. Prenat Diagn 1999; 19(12):1177-9.

66. Morris JK, Savva GM. The risk of fetal loss following a prenatal diagnosis of trisomy 13 or trisomy 18. Am J Med Genet A. 2008; 146(7):827-32.

67. Savva GM, Morris JK, Mutton DE, Alberman E. Maternal age-specific fetal loss rates in Down syndrome pregnancies. Prenat Diagn. 2006; 26(6):499-504.

68. Hook EB. Spontaneous deaths of fetuses with chromosomal abnormalities diagnosed prenatally. N Engl J Med. 1978; 299(19):1036-8.

69. Hook EB, Cross PK. Spontaneous abortion and subsequent Down syndrome livebirth. Hum Genet. 1983; 64(3):267-70.

70. Alberman E, Mutton D, Morris JK. Cytological and epidemiological findings in trisomies 13, 18, and 21: England and Wales 2004-2009. Am J Med Genet A. $2012 ; 158 \mathrm{~A}(5): 1145-50$.

71. Saenger P. Turner's syndrome. N Engl J Med. 1996; 335(23):1749-54.

72. Simpson JL, Rajkovic A. Ovarian differentiation and gonadal failure. Am J Med Genet. 1999; 89(4):186-200.

73. Robinson A, Bender BG, Borelli JB, Puck MH, Salbenblatt JA, Winter JS. Sex chromosomal aneuploidy: prospective and longitudinal studies. Birth Defects Orig Artic Ser. 1986; 22(3):23-71.

74. Robinson A, Bender BG, Linden MG. Prognosis of prenatally diagnosed children with sex chromosome aneuploidy. Am J Med Genet. 1992; 44(3):365-8.

75. Gravholt CH, Juul S, Naeraa RW, Hansen J. Prenatal and postnatal prevalence of Turners syndrome: a registry study. BMJ. 1996; 312(7022):16-21.

76. Surerus E, Huggon IC, Allan LD. Turners syndrome in fetal life. Ultrasound Obstet Gynecol. 2003; 22(3):264-7.

77. de Rosa G, Catalano D, DellIsola A. [Changes in fetal karyotype in nonimmune hydrops fetalis]. Minerva Ginecol. 1997; 49(12):535-9.

78. Hendricks SK, Sorensen TK, Baker ER. Trisomy 21, fetal hydrops, and anemia: prenatal diagnosis of transient myeloproliferative disorder? Obstet Gynecol. 1993; 82(4 Pt 2 Suppl):703-5.

79. Okeke TC, Egbugara MN, Ezenyeaku CC, Ikeako LC. Non-immune hydrops fetalis. Niger J Med. 2013; 22(4):266-73.

80. Landrum BG, Johnson DE, Ferrara B, Boros SJ, Thompson TR. Hydrops fetalis and chromosomal trisomies. Am J Obstet Gynecol. 1986; 154(5):1114-5.

81. Niedrist D, Riegel M, Achermann J, Rousson V, Schinzel A. Trisomy 18 changes in sex ratio during intrauterine life. Am J Med Genet A. 2006; 140(21):2365-7.

82. Brun JL, Gangbo F, Wen ZQ, Galant K, Taine L, Maugey-Laulom B, et al Prenatal diagnosis and management of sex chromosome aneuploidy: a report on 98 cases. Prenat Diagn. 2004; 24(3):213-8.

83. Has R, Recep H. Non-immune hydrops fetalis in the first trimester: a review of 30 cases. Clin Exp Obstet Gynecol. 2001; 28(3):187-90. 